\title{
Evaluation of supplementation plans for suckling beef calves managed on tropical pasture
}

\section{Avaliação de planos de suplementação para bezerros de corte lactentes manejados em pasto tropical}

\author{
Sidnei Antônio Lopes ${ }^{1 *}$; Mário Fonseca Paulino²; Edenio Detmann²; \\ Ériton Egídio Lisboa Valente ${ }^{3}$; Luciana Navajas Rennó²; Rilene Ferreira Diniz \\ Valadares ${ }^{4}$; Javier Enrique Garces Cardenas ${ }^{5}$; Daniel Mageste de Almeida ${ }^{5}$; \\ Felipe Henrique de Moura ${ }^{5}$; Camila Andressa Silva Oliveira ${ }^{5}$
}

\begin{abstract}
This study assessed the effects of different amounts of supplement on the productive performance, nutrional caracteristics and behaviour of suckling beef calves, as well as on the productive performance of their dams on tropical pastures. Forty-four male Nellore beef calves with an average age of 120 days and an initial average body weight (BW) of $145 \pm 3.7 \mathrm{~kg}$ and their respective dams, with an average BW of $449 \pm 6.9 \mathrm{~kg}$, were used. The amounts of supplement evaluated were as follows: $0=$ calves received only mineral mixture ad libitum; 3, 6, and $9=$ calves received 3, 6, or $9 \mathrm{~g} \mathrm{~kg}^{-1} \mathrm{BW}$ of supplement, respectively, containing $250 \mathrm{~g} \mathrm{CP} \mathrm{kg}^{-1}$ (as-fed). The experimental design was completely randomized. A positive linear effect $(\mathrm{P}<0.01)$ was observed in the intakes of dry matter and organic matter, and a cubic effect $(\mathrm{P}<0.07)$ was observed for the intake of neutral detergent fiber corrected for ash and protein. There was quadratic effect $(\mathrm{P}<0.06)$ for total digestibility of neutral detergent fiber. A cubic effect $(\mathrm{P}$ $<0.01$ ) was observed for the calves' performance. However, the calves' supplementation did not affect the milk yield and performance $(\mathrm{P} \geq 0.21)$ of their dams. The supplementation decreased grazing time $(\mathrm{P}<0.01)$ but did not influence suckling time $(\mathrm{P} \geq 0.59)$. It is recommended supplying of supplement containing $250 \mathrm{~g} \mathrm{CP} \mathrm{kg}^{-1}$ (as-fed) in amount $6 \mathrm{~g} \mathrm{~kg}^{-1} \mathrm{BW}$ to suckling beef calves managed in tropical pasture. Supplementation of suckling beef calves increases the intake of dry matter, decreases grazing time and forage intake. However, it does not affect the suckling time and productive performance of their dams.
\end{abstract}

Key words: Behavior. Calves. Creep feeding. Nellore. Supplementation.

\section{Resumo}

Este estudo avaliou os efeitos de diferentes quantidades de suplemento sobre o desempenho, características nutricionais e comportamentais de bezerros de corte lactentes, bem como o desempenho de suas mães em pasto tropical. Foram utilizados quarenta e quatro bezerros de corte lactentes machos da raça Nelore com idade média de 120 dias e peso corporal médio de $145 \pm 3,7 \mathrm{~kg}$, e suas respectivas mães,

\footnotetext{
${ }^{1}$ Dr. em Zootecnia., Departamento de Zootecnia, Universidade Federal de Viçosa, UFV, Viçosa, MG, Brasil. E-mail: sidneyufv@ hotmail.com

2 Profs., Departamento de Zootecnia, UFV, Viçosa, MG, Brasil. E-mail: mpaulino@ufv.br; detmann@ufv.br; lucianarenno@ufv.br

3 Prof., Departamento de Zootecnia, Universidade Estadual do Oeste do Paraná, UNIOESTE, Marechal Candido Rondon, PR, Brasil.E-mail. eritonvalente@yahoo.com.br

${ }^{4}$ Prof., Departamento de Medicina Veterinária, UFV, Viçosa, MG, Brasil. E-mail: rilene@ufv.br

5 Discentes, Pós-Graduação Departamento de Zootecnia, UFV, Viçosa, MG, Brasil. E-mail: yojavier1@hotmail.com; danielmagestedealmeida@hotmail.com; felipe.moura@ufv.br; camila.andressaoliveira@yahoo.com.br

* Author for correspondence
} 
com peso corporal médio de $449 \pm 6,9 \mathrm{~kg}$. As quantidades de suplemento avaliadas foram as seguintes: $0=$ bezerros receberam somente mistura mineral ad libitum; 3,6 ou $9=$ bezerros receberam 3,6 ou 9 $\mathrm{g} \mathrm{kg}^{-1} \mathrm{PC}$ de suplemento contendo $25 \mathrm{~g}$ de $\mathrm{PB} \mathrm{kg}{ }^{-1}$ (matéria natural). $\mathrm{O}$ delineamento experimental foi inteiramente casualizado. Foi observado efeito linear positivo $(\mathrm{P}<0,01)$ para o consume de matéria seca e matéria orgânica, e um efeito cúbico $(\mathrm{P}<0,07)$ foi observado para o consume de fibra em detergente neutro (FDN). Houve um efeito quadrático $(\mathrm{P}<0,06)$ para a digestibilidade total da FDN. Observou-se efeito cúbico $(\mathrm{P}<0,01)$ quanto ao desempenho dos bezerros. No entanto, a suplementação não afetou $(\mathrm{P} \geq 0,21)$ a produção de leite e o desempenho de suas mães. A suplementação diminuiu o tempo de pastejo $(\mathrm{P}<0,01)$, mas não influenciou $(\mathrm{P} \geq 0,59)$ o tempo de amamentação dos bezerros. Recomenda-se o fornecimento de suplemento contendo $25 \mathrm{~g} \mathrm{~PB} \mathrm{~kg}^{-1}$ na quantidade de $6 \mathrm{~g} \mathrm{~kg}^{-1} \mathrm{PC}$ para bezerros de corte lactentes manejados em pastagem tropical. A suplementação de bezerros de corte lactentes aumenta o consumo de matéria seca, diminui o tempo de pastejo e o consumo de forragem. Contudo, não influencia o tempo de amamentação e o desempenho produtivo de suas mães.

Palavras-chave: Bezerros. Comportamento. Creep feeding. Nelore. Suplementação.

\section{Introduction}

In the production of grazing young beef cattle in the tropics, weaning weight is one of the most important indicators related to production system efficiency. During the first few weeks of life, milk is the main source of energy and nutrient for young beef calves. Starting at about three months of age, however, milk is no longer sufficient for supplying their requirements (HENRIQUES et al., 2011). Thus, supplementation of suckling calves by creep feeding can therefore result in better performance and higher body weight (BW) at weaning (PAULINO et al., 2012).

Studies in the tropics on creep feeding have consistently shown an increase in the weaning weight of calves (PORTO et al., 2009; VALENTE et al., 2013; LOPES et al., 2014). Studies have also suggested that calves' supplementation by creep feeding could influence the behavior of calves, reducing their suckling time and frequency. Thus, cows' milk may be reduced due to a reduction in suckling stimulation (FORDYCE et al., 1996). As a result, this could have an influence on cow performance. Few studies have evaluated the behavior of beef calves in creep-feeding system, however, and still questions remain about the amounts of supplements used, which may influence the biological response of beef calves managed in tropical pasture.
The objective of this study was thus to evaluate the effect of different amounts of supplement on the productive performance, nutritional characteristics and behaviour of suckling beef calves, as well as on the productive performance of their dams on tropical pastures.

\section{Material and Methods}

All procedures involving animals were approved by the Institutional Committee of Universidade Federal de Viçosa for animal care and use experimentation, process UFV number 43/2014.

\section{Animals, experimental design and diets}

The experiment was conducted in the beef cattle sector at the Universidade Federal de Viçosa, Viçosa-MG, Brazil $\left(20^{\circ} 45^{\prime} \mathrm{S} 42^{\circ} 52^{\prime} \mathrm{W}\right)$, in a 40 -ha area with four paddocks for grazing with continuous stocking. This study was carried out during the transition phase between rainy and dry seasons from February to June 2013. Over days of measurements, the average minimum and maximum temperatures were $16.3 \pm 1.1^{\circ} \mathrm{C}$ and $26.1 \pm 1.0^{\circ} \mathrm{C}$ respectively. The average rainfall for the period was $107.9 \pm 33.3 \mathrm{~mm}$ (Department of Agricultural Engineering - UFV).

Forty-four Nellore beef calves males in the suckling phase averaging age of 120 days and $145 \pm 3.7 \mathrm{~kg}$ of initial body weight (BW), and their 
respective dams averaging 5 years-old and $449 \pm 6.9$ $\mathrm{kg}$ of BW were used. The experimental design was completely randomized with four treatments and eleven replicates. The treatments for the calves were: 0 = calves received only mineral mixture;
3,6 , and $9=$ calves received 3,6 , or $9 \mathrm{~g} \mathrm{~kg}^{-1} \mathrm{BW}$ of supplement. The supplement was formulated to contain $250 \mathrm{~g} \mathrm{CP} \mathrm{kg}^{-1}$ as-fed (Table 1), plus mineral mixture, which was weighed and mixed with supplement to be supplied to the group of calves daily.

Table 1 Supplement composition $\left(\mathrm{g} \mathrm{kg}^{-1}\right)$ as fed.

\begin{tabular}{lc}
\hline Ingredient & Amount \\
Ground corn grain & 260 \\
Ground sorghum grain & 260 \\
Soybean meal & 450 \\
Molasses & 30 \\
Mineral mixturea & 40 \\
\hline${ }^{\mathrm{a}}$ mineral mixture composition: dicalcium phosphate $\left(500.0 \mathrm{~g} \mathrm{~kg}^{-1}\right)$, sodium chloride $\left(471.9 \mathrm{~g} \mathrm{~kg}^{-1}\right), \mathrm{zinc}^{\mathrm{a}}$ sulfate $\left(15.0 \mathrm{~g} \mathrm{~kg}^{-1}\right), \mathrm{copper}^{-1}$ \\
sulfate $\left(7.0 \mathrm{~g} \mathrm{~kg}^{-1}\right)$, cobalt sulfate $\left(0.5 \mathrm{~g} \mathrm{~kg}^{-1}\right)$, potassium iodide $\left(0.5 \mathrm{~g} \mathrm{~kg}^{-1}\right)$, sodium selenite $\left(0.1 \mathrm{~g} \mathrm{~kg}^{-1}\right)$ and manganese sulfate $(5.0$ \\
$\left.\mathrm{g} \mathrm{kg}^{-1}\right)$.
\end{tabular}

Each group was managed on a 10-ha paddock with Brachiaria decumbens pastures. In each paddock, there were private feeders for each group of calves ( $0.5 \mathrm{~m}$ per calf); where the cows had no access. The calves' supplement was provided daily at 11 a.m at feeders, where calves had free access. Cows received a mineral mixture ad libitum (Table 1).

In order to minimize the possible effects of paddocks on the experimental treatments, animals were rotated among the paddocks every 7 days, so that each group stayed on each paddock for the same period of time.

\section{Experimental procedures and sampling}

Animals were submitted to 10 days of adaptation to the diet and experimental area, and 140 days of evaluation. For performance evaluation, the animals were weighed at the beginning and end of the experiment after 14 hours of fasting. At the beginning of the experiment, and every 28 days thereafter, the calves were weighed without fasting (and always in the morning at 6h00) in order to adjust the amount of supplement to be provided to each group. The BCS of the cows was evaluated at the beginning and end of the experiment by the same four trained evaluators, using a scale of 1 to 9 , as recommended by the NRC (1996).

The diurnal behavior of calves was monitored by human observation. Each group was observed for two non-consecutive days (from $6 \mathrm{~h} 00$ to $18 \mathrm{~h} 00$ ) in each paddock, totaling eight days of observations for each group. The behavior was carried out using the continuous focal animal recording method. The observers stayed at a distance of approximately 50 $\mathrm{m}$ from the animals (VALENTE et al., 2013). The behavior observed was the time the animals spent grazing, idling, suckling, and feeding.

Forage samples were collected every 28 days, from day 14 of the experiment, to evaluate forage availability. In each paddock, four samples of forage were randomly selected using a metallic square $(0.5$ $\times 0.5 \mathrm{~m}$ ) and cut approximately $1 \mathrm{~cm}$ above the ground. Sampling for the qualitative assessment of forage consumed by the animals was obtained every fourteen days by the hand-plucking method. All the samples were oven-dried $\left(60^{\circ} \mathrm{C} 72^{-1}\right.$ hours $)$ and ground in a Wiley mill (model 3, Arthur H. Thomas, 
Philadelphia, PA) to pass through a $2 \mathrm{~mm}$ screen. After that, half of each ground sample was ground again to pass through a $1 \mathrm{~mm}$ screen.

To estimate milk yield, cows were milked at days 35, and 90 of the experiment. Cows were separated from their calves at $18 \mathrm{~h} 00$. At $6 \mathrm{~h} 00$ of the following day, cows were injected with $2 \mathrm{~mL}$ oxytocin (10 IU $\mathrm{mL}^{-1}$; Ocitovet ${ }^{\circledR}$, Brazil) in the mammary artery and immediately milked. The exact time when each cow was milked was recorded, and the milk produced was proportionally converted into a $24 \mathrm{~h}$ based production. The milk produced was corrected to $4 \%$ of fat (FCM) according to NRC (2001):

$\mathrm{FCM}=0.4 \times$ milk yield $(\mathrm{kg} / \mathrm{d})+15 \times$ fat yield $(\mathrm{kg} / \mathrm{d}) \quad[1]$

Seventy days after the beginning of the experiment, a nine-day assay was carried out to evaluate voluntary intake and digestibility of the calves. Chromium oxide $\left(\mathrm{Cr}_{2} \mathrm{O}_{3}\right)$, used to estimate fecal excretion, was packaged in paper cartridges in the amount of $10 \mathrm{~g}$ per calf $\mathrm{d}^{-1}$ and was introduced (11h00) into the esophagus via a rubber tube; while titanium dioxide $\left(\mathrm{TiO}_{2}\right)$, used to estimate individual supplement intake, was mixed with the supplement distributed to the calves in an amount equal to $10 \mathrm{~g}$ per animal $\mathrm{d}^{-1}$. The first 6 days were used to stabilize the flow of markers in gastrointestinal tract of the animals, while the last 3 days were used for feces collection at $16 \mathrm{~h} 00$ on day 7 , at $11 \mathrm{~h} 00$ on day 8 , and at 6 h00 on day 9. The fecal samples were collected immediately after animal defecation or directly in the rectum, at the approximate amount of $200 \mathrm{~g}$. Then the samples oven-dried $\left(60^{\circ} \mathrm{C} 72^{-1}\right.$ hours) and proportionally pooled per animal, then ground in a Wiley mill (model 3, Arthur H. Thomas, Philadelphia, PA) to pass through a $2 \mathrm{~mm}$ screen. After that, half of each ground sample was ground again to pass through a $1 \mathrm{~mm}$ screen. In the fifth day of the digestibility assay, a sample of forage in each paddock was obtained by the hand-plucking method, to estimate voluntary intake and digestibility.
To evaluate the microbial protein production of calves, spot urine samples $(10 \mathrm{~mL})$ were collected from spontaneous micturition 4 hours after supply of supplement in the $80^{\text {th }}$ experimental day. Urine samples were diluted in $40 \mathrm{~mL}$ of $\mathrm{H}_{2} \mathrm{SO}_{4}(0.036 \mathrm{~N})$ and frozen $\left(-20^{\circ} \mathrm{C}\right)$. After urine collection, blood samples were collected by jugular vein puncture, using vacuum tubes with separator gel (BD Vacutainer ${ }^{\circledR}$ SST II Advance), and centrifuged at $3000 \times \mathrm{g}$ for 15 minutes and the serum was then frozen $\left(-20^{\circ} \mathrm{C}\right)$.

\section{Chemical analysis}

Samples of forage, feces, and supplement processed to pass through $1 \mathrm{~mm}$ screen sieve were analyzed according to the standard analytical procedures of the Brazilian National Institute of Science and Technology in Animal Science (INCTCA) (DETMANN et al., 2012) for dry matter (DM; INCT-CA method G-003/1), ash (INCT-CA method $\mathrm{M}-001 / 1)$, crude protein (CP; INCT-CA method $\mathrm{N}-001 / 1$ ), ether extract (EE; INCT-CA method G-004/1), neutral detergent fiber (NDFap; INCT-CA method F-002/1), using alpha thermostable amylase without addition of sodium sulfite and corrected for ash and protein (NDIP; INCT-CA method N-004/1). Indigestible neutral detergent fiber (iNDF; INCTCA method F-009/1) was quantified by in situ incubation procedures with F57 bags (Ankom ${ }^{\circledR}$ ) for 288 hours in samples processed at $2 \mathrm{~mm}$. In addition, fecal samples were evaluated for the contents of chromium (INCT-CA method M-005/1) and titanium (INCT-CA method M-007/1). Milk samples of each cow were analyzed with regards as protein, fat, lactose, and total solids content using infrared spectroscopy (Foss MilkoScan FT120, Hillerød, Denmark).

The percentage of potentially digestible DM (DMpd) in the forage samples obtained for evaluation of forage availability was estimated according to Paulino et al. (2008): 


$$
D M p d=0.98 \times(100-N D F)+(N D F-i N D F)
$$

where: $\mathrm{DMpd}=$ forage content of potentially digestible DM (DM \%); 0.98 = true digestible coefficient of cell content; and NDF and iNDF = forage content of NDF and iNDF, respectively (DM $\%)$.

Fecal excretion was estimated by rationing the quantity of chromic oxide offered and the concentration in feces.

Individual DM intake of the supplement (DMS) was estimated by relation of excretion of $\mathrm{TiO}_{2}$ in feces and marker concentration in the supplement.

The voluntary intake of DM from forage (DMF) was estimated using an internal iNDF according to Detmann et al. (2001), using the following equation:

$D M F=[(F E \times i N D F f e c e s)-D M S i \times i N D F$ sup $] \div i N D F f o r a g e$

where $\mathrm{FE}=$ fecal excretion $\left(\mathrm{Kg} \mathrm{d}^{-1}\right)$, iNDFfeces $=$ concentration of iNDF in the feces $\left(\mathrm{kg} \mathrm{kg}^{-1}\right)$, DMSi $=$ dry matter supplement intake $\left(\mathrm{kg} \mathrm{d}^{-1}\right)$, iNDFSup $=$ concentration of iNDF in the supplement $\left(\mathrm{kg} \mathrm{kg}^{-}\right.$ ${ }^{1}$ ), and iNDFforage $=$ concentration of iNDF in the forage $\left(\mathrm{kg} \mathrm{kg}^{-1}\right)$.

The total DM intake was calculated by the sum of DMF intake, DMS intake, and DM milk intake (DMM).

In the samples of urine, analyses were carried out for creatinine, uric acid and urea by methods colorimetric kinetic, enzymatic colorimetric and kinetic fixed time, respectively, using automatic biochemical analyzer (Mindray, BS200E model).

Daily urinary volume was estimated using the relationship between the daily creatinine excretion (CE), taking as reference the equation proposed by Costa e Silva et al. (2012), and its concentration in the spot samples:

$$
\mathrm{CE}(\mathrm{g} / \mathrm{d})=0.0345 \times \mathrm{SBW}^{0.9491}
$$

where: SBW = shrunk body weight

Allantoin was analyzed by the colorimetric method as described by Chen and Gomes (1992). Total excretion of purine derivatives was calculated by the sum of the amounts of allantoin and uric acid excreted in urine.

The purines absorbed were calculated from the excretion of purine derivatives according to Barbosa et al. (2011):

$$
A P=\frac{\left(P D-0.301 \times B W^{0.75}\right)}{0.80}
$$

where: $\mathrm{AP}=$ absorbed purines $\left(\mathrm{mmol} \mathrm{d}^{-1}\right) ; \mathrm{PD}=$ excretion of purine derivative $\left(\mathrm{mmol} \mathrm{d}^{-1}\right) ; 0.301=$ endogenous excretion of purine derivative in the urine (mmol) per unit of metabolic weight $\left(\mathrm{BW}^{0.75}\right)$; and $0.80=$ recovery of purine absorbed as purine derivative in the urine $\left(\mathrm{mmol} \mathrm{mmol}{ }^{-1}\right)$.

Ruminal synthesis of microbial nitrogen compounds was calculated as a function of AP using the equation described by Barbosa et al. (2011).

$$
N M I C=\frac{(70 x A P)}{(0.93 \times R \times 1000)}
$$

where: $\mathrm{NMIC}=$ intestinal flow of microbial nitrogen compounds $\left(\mathrm{g} \mathrm{d}^{-1}\right) ; 70=\mathrm{N}$ content in the purines $(\mathrm{mg}$ $\left.\mathrm{N} \mathrm{mol}^{-1}\right) ; 0.93=$ digestibility of microbial purines and $\mathrm{R}=0.134=\mathrm{N}$ purine: total $\mathrm{N}$ in the bacteria according to Valadares et al. (1999).

\section{Statistical analysis}

The experiment was carried out according to a completely randomized design, including the fixed effect of treatments and using the initial BW as a covariate. The comparisons among treatments were performed out by orthogonal decomposition of the sum of squares of the treatments in linear, quadratic, and cubic effects related to the effects of supplement 
amounts. All statistical procedures were performed adopting 0.10 as the critical level of probability for the type I error and the MIXED procedure of the Statistical Analysis System 9.4 (SAS Institute, Inc.).

\section{Results}

The average availability of DM and DMpd during the experiment was 4.4 and $2.5 \mathrm{t} \mathrm{ha}^{-1}$, respectively, which corresponded to the momentary mean availability of 256.2 and $148.3 \mathrm{~g} \mathrm{~kg}^{-1} \mathrm{BW}$. The forage sampled by hand-plucking had an average CP content of $86 \mathrm{~g} \mathrm{~kg}^{-1} \mathrm{DM}$ (Table 2).

The observed supplement intake occurred as planned in the supplementation plans, and orts were not observed. The average supplement intakes (asfed) throughout the study, were $2.9 \pm 0.02,5.7 \pm 0.03$ and $8.6 \pm 0.06 \mathrm{~g} \mathrm{~kg}^{-1} \mathrm{BW}$, which corresponded, in average, to $0.6,1.2$, and $1.8 \mathrm{~kg}$ animal ${ }^{-1} \mathrm{~d}^{-1}$ for the treatments 3,6 , or $9 \mathrm{~g} \mathrm{~kg}^{-1} \mathrm{BW}$, respectively.

The average milk yield and composition were not affected $(\mathrm{P} \geq 0.18)$ by the calves' supplementation (Table 3).

Table 2. Chemical composition of the supplements and forage.

\begin{tabular}{lccc}
\hline \multirow{2}{*}{ Item } & Supplement & \multicolumn{2}{c}{ Brachiaria decumbens } \\
\cline { 2 - 4 } & $\mathrm{g} \mathrm{kg}^{-1}$ as fed & & Forage $^{2}$ \\
$\mathrm{DM}$ & 945.0 & $295.2 \pm 0.4$ & $280.3 \pm 0.6$ \\
& $\mathrm{~g} \mathrm{~kg}^{-1} \mathrm{DM}$ & & \\
$\mathrm{OM}$ & 963.7 & $901.5 \pm 0.3$ & $903.5 \pm 0.4$ \\
$\mathrm{CP}$ & 275.6 & $86.1 \pm 0.2$ & $84.5 \pm 0.3$ \\
$\mathrm{EE}$ & 230.0 & $10.4 \pm 0.1$ & $7.8 \pm 0.1$ \\
$\mathrm{NDFap}$ & 177.4 & $630.4 \pm 0.9$ & $658.2 \pm 1.0$ \\
iNDF & 8.7 & $257.7 \pm 0.8$ & $254.9 \pm 0.4$ \\
NFC & 487.7 & $170.0 \pm 0.6$ & $152.9 \pm 1.2$ \\
\hline
\end{tabular}

$\mathrm{DM}=$ dry matter; $\mathrm{OM}=$ organic matter; $\mathrm{CP}=$ crude protein; $\mathrm{EE}=$ ether extract; NDFap = neutral detergent fiber corrected for ash and protein; $\mathrm{iNDF}=$ indigestible neutral detergent fiber; $\mathrm{NFC}=$ Non-fiber carbohydrate

${ }^{1}$ Mean \pm standard error of the mean (hand-plucked samples collected throughout study)

${ }^{2}$ Mean \pm standard error of the mean (hand-plucked samples collected during digestibility trial).

Table 3. Least squares means, standard error of the mean (SEM) and significance indicative for milk yield and composition of cows according to the supplement amount offered to the calves.

\begin{tabular}{|c|c|c|c|c|c|c|c|c|}
\hline \multirow{2}{*}{ Item } & \multicolumn{4}{|c|}{ Supplement amount $\left(\mathrm{g} \mathrm{kg}^{-1} \mathrm{BW}\right)$} & \multirow[b]{2}{*}{ SEM } & \multicolumn{3}{|c|}{$\mathrm{P}_{\text {value }}{ }^{1}$} \\
\hline & 0 & 3 & 6 & 9 & & $\mathrm{~L}$ & $\mathrm{Q}$ & $\mathrm{C}$ \\
\hline & $\mathrm{kg} \mathrm{d}^{-1}$ & & & & & & & \\
\hline Milk & 7.01 & 7.39 & 7.46 & 7.03 & 0.41 & 0.555 & 0.149 & 0.747 \\
\hline $\mathrm{FCM}^{2}$ & 7.48 & 7.87 & 7.97 & 7.11 & 0.45 & 0.559 & 0.124 & 0.622 \\
\hline & $\mathrm{g} \mathrm{kg}^{-1}$ & & & & & & & \\
\hline Fat & 46.63 & 44.21 & 45.75 & 46.39 & 0.14 & 0.899 & 0.282 & 0.442 \\
\hline Protein & 34.29 & 34.32 & 35.00 & 34.10 & 0.04 & 0.888 & 0.179 & 0.182 \\
\hline Lactose & 43.80 & 44.63 & 43.79 & 44.88 & 0.04 & 0.182 & 0.743 & 0.917 \\
\hline Total solids & 135.97 & 134.47 & 135.95 & 136.31 & 0.16 & 0.730 & 0.570 & 0.570 \\
\hline
\end{tabular}

${ }^{1} \mathrm{~L}, \mathrm{Q}$ and $\mathrm{C}=$ linear, quadratic and cubic effects of the supplement amount

${ }^{2} \mathrm{FCM}=4 \%$ fat-corrected milk yield. 
The intake of DM, OM, CP, and digestible organic matter $(\mathrm{DOM})$ increased linearly $(\mathrm{P}<0.01)$ with an increase in the amount of supplement supplied to the calves. DMF intake, however, decreased linearly $(\mathrm{P}<0.01)$ (Table 4). In addition, a cubic effect $(\mathrm{P}<0.07)$ was observed for NDF and iNDF intake (Table 4).

Table 4. Least squares means, standard error of the mean (SEM) and significance indicative for voluntary intake of calves according to the supplement amount offered to the calves.

\begin{tabular}{|c|c|c|c|c|c|c|c|c|}
\hline \multirow{2}{*}{ Item } & \multicolumn{4}{|c|}{ Supplement amount $\left(\mathrm{g} \mathrm{kg}^{-1} \mathrm{BW}\right)$} & \multirow[b]{2}{*}{ SEM } & \multicolumn{3}{|c|}{$\mathrm{P}_{\text {value }}{ }^{1}$} \\
\hline & 0 & 3 & 6 & 9 & & $\mathrm{~L}$ & Q & $\mathrm{C}$ \\
\hline & $\mathrm{kg} \mathrm{d}^{-1}$ & & & & & & & \\
\hline $\mathrm{DM}$ & 3.15 & 3.52 & 4.20 & 3.98 & 0.21 & 0.001 & 0.181 & 0.214 \\
\hline DMF & 2.29 & 1.99 & 2.06 & 1.70 & 0.11 & 0.004 & 0.813 & 0.139 \\
\hline DMM & 0.9 & 1.0 & 1.0 & 0.9 & 0.08 & 0.786 & 0.630 & 0.846 \\
\hline $\mathrm{OM}$ & 2.85 & 3.24 & 3.84 & 3.69 & 0.18 & 0.001 & 0.174 & 0.272 \\
\hline $\mathrm{CP}$ & 0.416 & 0.563 & 0.716 & 0.827 & 0.05 & $<0.001$ & 0.734 & 0.830 \\
\hline EE & 0.299 & 0.345 & 0.374 & 0.337 & 0.03 & 0.251 & 0.135 & 0.699 \\
\hline NDFap & 1.50 & 1.47 & 1.69 & 1.20 & 0.08 & 0.083 & 0.012 & 0.015 \\
\hline NFC & 0.35 & 0.51 & 0.70 & 1.09 & 0.06 & $<0.001$ & 0.079 & 0.528 \\
\hline iNDF & 0.56 & 0.51 & 0.56 & 0.45 & 0.03 & 0.046 & 0.376 & 0.068 \\
\hline DOM & 1.91 & 2.27 & 2.59 & 2.53 & 0.15 & 0.003 & 0.185 & 0.633 \\
\hline & $\mathrm{g} \mathrm{kg}^{-1} \mathrm{BW}$ & & & & & & & \\
\hline DM & 15.94 & 17.71 & 20.03 & 19.65 & 0.71 & 0.002 & 0.138 & 0.311 \\
\hline DMF & 11.65 & 10.00 & 9.87 & 8.49 & 0.51 & 0.002 & 0.805 & 0.250 \\
\hline $\mathrm{OM}$ & 14.43 & 16.32 & 18.39 & 18.22 & 0.65 & $<0.001$ & 0.126 & 0.416 \\
\hline NDFap & 7.64 & 7.40 & 8.13 & 6.00 & 0.36 & 0.014 & 0.013 & 0.023 \\
\hline
\end{tabular}

$\mathrm{DM}=$ dry matter, $\mathrm{DMF}=$ forage dry matter, $\mathrm{DMM}=$ milk dry matter, $\mathrm{OM}=$ organic matter, $\mathrm{CP}=$ crude protein, $\mathrm{EE}=$ ether extract, NDFap $=$ neutral detergent fiber corrected for ash and protein, $\mathrm{NFC}=$ Non-fiber carbohydrate, $\mathrm{iNDF}=$ indigestible neutral detergent fiber, $\mathrm{DOM}=$ digestible organic matter

${ }^{1} \mathrm{~L}, \mathrm{Q}$ and $\mathrm{C}=$ linear, quadratic and cubic effects of the supplement amount.

The different amounts of supplement did not affect $(\mathrm{P} \geq 0.59)$ the duration of breastfeeding. In average, the calves spent $3 \%$ of time suckling (Table 5). On the other hand, grazing time decreased linearly $(\mathrm{P}<0.01)$ with increased amount of supplement, and a cubic effect $(\mathrm{P}<0.01)$ was observed for feeding time (Table 5).

There were no differences $(P \geq 0.25)$ in total digestibility of $\mathrm{OM}, \mathrm{CP}$, and $\mathrm{EE}$; on the other hand, a quadratic effect $(\mathrm{P}<0.06)$ was observed for the digestibility of NDFap (Table 6). 
Table 5. Least squares means, standard error of the mean (SEM) and significance indicative for diurnal behavior of calves according to the supplement amount offered to the calves.

\begin{tabular}{|c|c|c|c|c|c|c|c|c|}
\hline \multirow{2}{*}{ Item } & \multicolumn{4}{|c|}{ Supplement amount $\left(\mathrm{g} \mathrm{kg}^{-1} \mathrm{BW}\right)$} & \multirow[b]{2}{*}{ SEM } & \multicolumn{2}{|c|}{ P value $^{1}$} & \multirow[b]{2}{*}{$\mathrm{C}$} \\
\hline & 0 & 3 & 6 & 9 & & $\mathrm{~L}$ & Q & \\
\hline$(\%)$ & Calves & & & & & & & \\
\hline Grazing & 33.39 & 33.07 & 32.55 & 27.76 & 1.28 & 0.003 & 0.503 & 0.707 \\
\hline Idle & 61.28 & 60.12 & 56.41 & 61.72 & 1.30 & 0.761 & 0.009 & 0.105 \\
\hline Suckling & 3.10 & 3.00 & 3.11 & 2.81 & 0.31 & 0.597 & 0.728 & 0.663 \\
\hline Feeding & 2.23 & 3.81 & 7.93 & 7.71 & 0.55 & $<0.001$ & 0.111 & 0.008 \\
\hline
\end{tabular}

${ }^{1} \mathrm{~L}, \mathrm{Q}$ and $\mathrm{C}=$ linear, quadratic and cubic effects of the supplement amount.

Table 6. Least squares means, standard error of the mean (SEM) and significance indicative for digestibility and synthesis of microbial nitrogen compounds according to the supplement amount offered to the calves.

\begin{tabular}{|c|c|c|c|c|c|c|c|c|}
\hline \multirow{2}{*}{ Item } & \multicolumn{4}{|c|}{ Supplement amount ( $\left.\mathrm{g} \mathrm{kg}^{-1} \mathrm{BW}\right)$} & \multicolumn{4}{|c|}{$\mathrm{P}_{\text {value }}{ }^{1}$} \\
\hline & 0 & 3 & 6 & 9 & SEM & $\mathrm{L}$ & Q & $\mathrm{C}$ \\
\hline $\mathrm{OM}$ & 66.80 & 69.54 & 67.15 & 68.47 & 1.21 & 0.625 & 0.553 & 0.105 \\
\hline $\mathrm{CP}$ & 63.77 & 67.34 & 64.67 & 68.42 & 2.15 & 0.251 & 0.964 & 0.200 \\
\hline EE & 82.51 & 86.66 & 84.17 & 84.87 & 1.75 & 0.569 & 0.339 & 0.226 \\
\hline NDFap & 61.53 & 59.72 & 57.51 & 49.87 & 1.51 & $<0.001$ & 0.056 & 0.451 \\
\hline NFC & 50.51 & 67.19 & 65.46 & 76.14 & 2.71 & $<0.001$ & 0.283 & 0.017 \\
\hline DOM & 605 & 641 & 616 & 635 & 11.2 & 0.194 & 0.435 & 0.042 \\
\hline NMIC & 23.97 & 35.63 & 33.24 & 34.74 & 2.61 & 0.017 & 0.069 & 0.152 \\
\hline NMIC/NI & 0.41 & 0.40 & 0.28 & 0.28 & 0.05 & 0.018 & 0.933 & 0.295 \\
\hline EMS & 80.72 & 92.94 & 82.20 & 89.21 & 7.41 & 0.652 & 0.725 & 0.229 \\
\hline SUN & 11.35 & 13.17 & 17.41 & 18.95 & 0.91 & $<0.001$ & 0.882 & 0.220 \\
\hline UNUE & 24.44 & 31.85 & 43.72 & 43.42 & 2.21 & $<0.001$ & 0.109 & 0.111 \\
\hline
\end{tabular}

$\mathrm{OM}=$ organic matter, $\mathrm{CP}=$ crude protein, $\mathrm{EE}=$ ether extract, $\mathrm{NDFap}=$ neutral detergent fiber corrected for ash and protein, $\mathrm{NFC}$ $=$ Non-fiber carbohydrate, $\mathrm{DOM}=$ digestible organic matter $\left(\mathrm{g} \mathrm{kg}^{-1} \mathrm{DM}\right), \mathrm{NMIC}=$ intestinal flow of microbial nitrogen compounds $\left(\mathrm{g} \mathrm{d}^{-1}\right), \mathrm{NMIC} / \mathrm{NI}=$ NMIC in relation to nitrogen intake $\left(\mathrm{g} \mathrm{g}^{-1}\right.$ ingested $\left.\mathrm{N}\right), \mathrm{EMS}=$ efficiency of microbial protein synthesis $(\mathrm{g}$ microbial CP synthesis $\mathrm{kg}^{-1} \mathrm{DOM}$ intake), $\mathrm{SUN}=$ serum urea nitrogen $\left(\mathrm{mg} \mathrm{dL}^{-1}\right), \mathrm{UNUE}=$ ureic nitrogen urinary excretion $\left(\mathrm{g} \mathrm{d}^{-1}\right)$ ${ }^{1} \mathrm{~L}, \mathrm{Q}$ and $\mathrm{C}=$ linear, quadratic and cubic effects of the supplement amount.

A quadratic effect $(\mathrm{P}<0.08)$ was observed in the amount of supplement on the intestinal flow of microbial nitrogen compounds (NMIC); no differences were found $(\mathrm{P} \geq 0.65)$, however, in the efficiency of microbial protein synthesis (EMS). In addition, the NMIC in relation to nitrogen intake (NMIC/NI) decreased linearly $(\mathrm{P}<0.02)$ with increases in the amount of supplement provided to calves. A positive linear effect of amount of supplement $(\mathrm{P}<0.01)$ was observed in the urea nitrogen excretion in the urine (UUN) and the concentration of serum urea nitrogen (SUN) (Table 6).
The calves' supplementation did not affect $(\mathrm{P}>0.21)$ the FBW and FBCS of their dams. A cubic effect $(\mathrm{P}<0.01)$, however, was observed in the calves' performance with increases in amount of supplement (Table 7). Supplement use efficiency (the additional weight gain of the supplemented calves/supplement intake) was $0.15,0.17$, and 0.09 for amounts of supplements 3, 6, or $9 \mathrm{~g} \mathrm{~kg}^{-1} \mathrm{BW}$, respectively. 
Table 7. Least squares means, standard error of the mean (SEM) and significance indicative for performance of calves and cows according to the supplement amount offered to the calves.

\begin{tabular}{|c|c|c|c|c|c|c|c|c|}
\hline \multirow{2}{*}{ Item } & \multicolumn{4}{|c|}{ Supplement amount ( $\left.\mathrm{g} \mathrm{kg}^{-1} \mathrm{BW}\right)$} & \multirow[b]{2}{*}{ SEM } & \multicolumn{2}{|c|}{$\mathrm{P}_{\text {value }}{ }^{1}$} & \multirow[b]{2}{*}{ C } \\
\hline & 0 & 3 & 6 & 9 & & $\mathrm{~L}$ & Q & \\
\hline & Calves & & & & & & & \\
\hline FBW, kg & 246.4 & 258.3 & 275.4 & 269.6 & 3.70 & $<0.001$ & 0.021 & 0.095 \\
\hline $\mathrm{ADG}$ & $\begin{array}{c}0.72 \\
\text { Cows }\end{array}$ & 0.80 & 0.92 & 0.89 & 0.03 & $<0.001$ & 0.021 & 0.095 \\
\hline FBW & 465.5 & 462.5 & 465.9 & 473.6 & 4.65 & 0.212 & 0.253 & 0.924 \\
\hline FBCS & 4.53 & 4.61 & 4.54 & 4.73 & 0.08 & 0.139 & 0.539 & 0.271 \\
\hline
\end{tabular}

$\mathrm{FBW}=$ final body weight in $\mathrm{kg}, \mathrm{ADG}=$ average daily gain in $\mathrm{kg}, \mathrm{FBCS}=$ final body condition score

${ }^{1} \mathrm{~L}, \mathrm{Q}$ and $\mathrm{C}=$ linear, quadratic and cubic effects of the supplement amount.

\section{Discussion}

According to Detmann et al. (2014a), positive effect on the utilization of energy substrates from forage has been observed with increasing dietary $\mathrm{CP}$ content up to $100 \mathrm{~g} \mathrm{~kg}^{-1} \mathrm{DM}$. In addition, voluntary intake forage have been stimulated with concentrations of up to $145 \mathrm{~g} \mathrm{CP} \mathrm{kg}^{-1} \mathrm{DM}$ (DETMANN et al., 2014b). Thus, supplementation may increase dietary $\mathrm{CP}$ content and could optimize the utilization and intake of forage and, as a result, animal performance.

In fact, in our study there was a linear increase in the intake of DM and OM, which occurred directly by increased in the supplying of supplement, resulting in increased animal performance. However, there was a substitutive effect of the intake of the supplement that was offered on forage intake, fact that may be confirmed by decrease in grazing time of the calves. It was observed a reduction of $25 \%$ in the forage intake for the greater amounts of supplement provided. Some authors have associated the dietary protein to energy $(\mathrm{P}: \mathrm{E})$ ratio, represented by the ratio $\mathrm{CP}$ : DOM, with variations in the voluntary intake of forage (COSTA et al., 2011; DETMANN et al., 2014b). In a recent approach, Detmann et al. (2014b) inferred that the maximum voluntary intake of tropical forages is observed with the ratio of $288 \mathrm{~g} \mathrm{CP} \mathrm{kg}^{-1} \mathrm{DOM}$. The CP:DOM ratio observed in our study was 217.4, 248.0, 276.4, and 326.9 for the amounts of supplement $0,3,6$, or 9 $\mathrm{g} \mathrm{kg}^{-1} \mathrm{BW}$, respectively. Thus, it is understood that providing higher amounts of supplement would increase further more the dietary imbalance in the ratio $\mathrm{CP}$ : DOM, with a decrease in forage intake by metabolic mechanisms (COSTA et al., 2011; DETMANN et al., 2014b) explaining, therefore, the behavior observed in this study.

In view of variety of experimental conditions, variable results have it has been found in the literature. Such differences may be attributed to differences in composition of supplements and forage, amount of supplement provided, type of forage and the milk yield of the cows. Overall, several authors (PAULA, 2012; BARROS et al., 2014; LOPES et al., 2014) evaluated the effects of calves' supplementation on the nutritional characteristics and have found decrease in forage intake.

By analyzing the intake of each treatment it was observed that the provision of supplements in the amount of $6 \mathrm{~g} \mathrm{~kg}^{-1} \mathrm{BW}$ allowed a ratio of $276.4 \mathrm{CP} \mathrm{kg}^{-1}$ DOM close to the ratio suggested by the Detmann et al. (2014b); and this reflected numerically in greater intake, and, consequently, greater animal performance. Thus, the supplying of $6 \mathrm{~g} \mathrm{~kg}^{-1}$ presented an appropriate balance of protein and energy, where it occurred a supply of protein deficit dietary with appropriate energy offer. This allowed an efficient utilization of protein (SOUZA et al., 2010) and a greater availability of metabolizable energy and protein for animal metabolism to tissue 
synthesis. On the other hand, it was observed a reduction in performance by providing supplements in the amount of $9 \mathrm{~g} \mathrm{~kg}^{-1} \mathrm{BW}$. This fact can be explained by occurrence of an excess of protein in animal metabolism, confirmed by the CP:DOM ratio higher than $288 \mathrm{~g} \mathrm{CP} \mathrm{kg}^{-1}$ DOM (DETMANN et al., 2014b). In ruminants, the protein deposition efficiency depends on the availability of energy, as the energy use efficiency depends on the availability in the metabolism of amino acids (SCHROEDER; TITGEMEYER, 2008).

Overall, protein supplementation increases the degradation rates of potentially digestible NDF in the rumen and enlargement of forage voluntary intake (DETMANN et al., 2011). Lazzarini et al. (2009) suggested 70-80 $\mathrm{g}$ of $\mathrm{CP} \mathrm{kg}^{-1} \mathrm{DM}$ as a minimum so there is no impairment of ruminal microbial growth and thus to occur efficient utilization of the fiber of the forage. According these authors, small benefits have been observed in response to protein supplementation in situations where the available nitrogen is sufficient to support microbial growth. Moreover, in the suckling phase, the rumens of calves are still in the development stage, which makes the calves more susceptible to digestive disorders; as such they are less able to utilize rough feed. These arguments, together with the low participation of NDFap in the diet, may have contributed to a reduction in NDFap digestibility observed in our study; in addition, increased amounts of the supply of supplements have been reported to have deleterious effects on the digestibility of NDFap (PAULA, 2012). Others studies (MARQUEZ et al., 2014; LOPES et al., 2014) involving calve's supplementation during suckling phase, have also shown absence of effect or reduction in NDF digestibility.

The amounts of supplement assessed did not affect the calves' suckling behavior. As consequence, the calves' DM intake of milk (Table 4) did not differ between treatments, indicating that calves does not replace milk by supplement; therefore, this was not a factor that would interfere in the difference in performance among calves. On the other hand, there was an increase in the intake of CP, DOM, and NFC, which resulted from increases in the supplement supply; this reflected in higher performance. This fact shows that during the suckling period, the nutrients available from milk and tropical forage alone were not sufficient for supplying the nutritional requirements for maximal weight gain. This result is similar to other studies (VALENTE et al., 2013; LOPES et al., 2014; BARROS et al., 2014) that have also found increases in performance due to creep feeding. According to Paulino et al. (2010), beef calves weighting of $200 \mathrm{~kg}$ and an ADG of 1 $\mathrm{kg} \mathrm{d}^{-1}$ require a daily intake of 3.0 of total digestible nutrients (TDN) and $0.708 \mathrm{~kg}$ of $\mathrm{CP}$, respectively. It was observed that the provision of $6 \mathrm{~g} \mathrm{~kg}^{-1} \mathrm{BW}$ allowed an intake of energy and protein that was close to that suggested by the authors cited above.

According to Paulino et al. (2014), in order to enable the production of young beef cattle on tropical pastures, a feeding management system should be established that will allow weight gains from birth until slaughter at 16 months of about $900 \mathrm{~g}_{\text {animal }}{ }^{-1} \mathrm{~d}^{-1}$. This performance was obtained by providing supplement in the amount of $6 \mathrm{~g} \mathrm{~kg}^{-1}$ $\mathrm{BW}$, which provided an additional gain of $200 \mathrm{~g} \mathrm{~d}^{-1}$ in relation to the nutritional plan $0 \mathrm{~g} \mathrm{~kg}^{-1} \mathrm{BW}$. This observation corroborates statements made by Poppi and McLennan (1995); and Paulino et al. (2008) that stated that it is possible to obtain an additional gain of 200-300 $\mathrm{g} \mathrm{d}^{-1}$ with the use of supplements when the forage grazed has good nutritional quality.

According to Vargas Junior et al. (2011), milk yield may be increased as the calf stimulates the mammary gland. A high frequency of suckling could make the cow increase milk yield in response to higher stimulation; as result, this may reduce her body condition. On the other hand, as the calf grows, its ability to eat solid feed increases while its milk intake decreases; the adoption of supplementation can thus reduce dependence of calves in relation to cows' productivity levels, resulting in lower variations in body condition. In our study, however, 
the milk yield was not affected by calves' treatments. Consequently, we did not observe any effect on cows' performance due to the calves' treatments. Similarly, other studies (VALENTE et al., 2013; BARROS et al., 2014) also did not find differences in milk yield and productive performance in beef cows due to calves' supplementation.

This likely occurred because calves prefer milk, supplement and forage, in that order; it thus seems unlikely that calves would replace milk by supplements. Calves will therefore usually increase supplement and forage intake only after maximizing milk intake. In our study, we did not observe differences in suckling times for different amounts of supplement, which is similar to results found by Valente et al. (2013). With increased amount of supplements, however, calves were less dependent upon pasture to supply their nutritional demands, and they spent less time grazing, which indicates the replacement of forage intake by supplements. Similarly, other studies (LOPES et al., 2014; CARDENAS et al., 2015) have also observed that there were no changes in dry matter milk intake; although forage intake was lower for supplemented calves. In that way, it seems unlikely that calves' supplementation may have some effect on the cow.

\section{Conclusions}

From the results obtained of this study, it is recommended the provision of supplement containing $250 \mathrm{~g} \mathrm{CP} \mathrm{kg}^{-1}$ in the amount of $6 \mathrm{~g} \mathrm{~kg}^{-1}$ BW to suckling beef calves managed in tropical pasture. Supplementation of suckling beef calves increases intake of dry matter, and decreases grazing time and forage intake. However, it does not affect suckling time and productive performance of their dams.

\section{Acknowledgment}

The authors wish to thank the Instituto Nacional de Ciência e Tecnologia de Ciência Animal (INCT-CA),
Fundação de Amparo à Pesquisa de Minas Gerais (FAPEMIG), Coordenação de Aperfeiçoamento de Pessoal de Nível Superior (CAPES) and Conselho Nacional de Desenvolvimento Científico e Tecnológico (CNPq, Brazil) for financial support.

\section{References}

BARBOSA, A. M.; VALADARES, R. F. D.; VALADARES FILHO, S. C.; PINA, D. S.; DETMANN, E.; LEÃO, M. I. Endogenous fraction and urinary recovery of purine derivatives obtained by different methods in Nellore cattle. Journal of Animal Science, Champaign, v. 89, n. 2, p. 510-519, 2011.

BARROS. L. V.; PAULINO, M. F.; CHIZZOTTI, M. L.; RENNÓ, L. N.; CARDENAS, J. E. G.; VALENTE, E. E. L.; LOPES, S. A.; CABRAL, C. H. A.; PAULA, N. F.; SILVA, F. G. Supplementation of female calves in creep feeding system and productive and nutritional parameters of beef cows on tropical pasture. Semina: Ciências Agrárias, Londrina, v. 35, n. 4, p. 2723-2738, 2014.

CARDENAS, J. E. G.; PAULINO, M. F.; LOPES, S. A.; SILVA, A. G.; BARROS, L. V.; VALENTE, E. E. L. Performance productive, intake and digestibility of nursing calves raised on pasture supplemented with different levels of crude protein. Archivos de Zootecnia, Córdoba, v. 64, n. 246, p. 167-174, 2015.

CHEN, X. B.; GOMES, M. J. Estimation of microbial protein supply to sheep and cattle basid on urinary excretion of purine derivatives: an overview of the technical details. Aberdeen: Ed. Buchsburnd Aberdeen, International Feed Resources Unit, Rowett Research Institute, 1992. 21 p. (Ocasional publication).

COSTA E SILVA, L. F.; VALADARES FILHO, S. C.; CHIZOTTI, M. L.; ROTTA, P. P.; PRADOS, L. F.; DINIZ, R. F.; ZANETTI, D.; BRAGA, J. M. S. Creatinine excretion and relationship with body weight of Nellore cattle. Revista Brasileira de Zootecnia, Viçosa, MG, v. 41, n. 3, p. 807-810, 2012.

COSTA, V. A. C.; DETMANN, E.; PAULINO, M. F.; VALADARES FILHO, S. C.; CARVALHO, I. P. C.; MONTEIRO, L. P. Intake and digestibility in cattle under grazing during rainy season and supplemented with different sources of nitrogenous compounds and carbohydrates. Revista Brasileira de Zootecnia, Viçosa, MG, v. 40, n. 8, p. 1788-1798, 2011. 
DETMANN, E.; PAULINO, M. F.; ZERVOUDAKIS, J. T.; VALADARES FILHO, S. C.; EUCLIDES, R. F.; LANA, R. P.; QUEIRÓZ, D. S. Chromium and internal markers to estimate the intake of crossbred steers, supplemented steers on pasture. Revista Brasileira de Zootecnia, Viçosa, MG, v. 30, n. 5, p. 1600-1609, 2001.

DETMANN, E.; QUIROZ, A. C.; ZORZI, K.; MANTOVANI, H. C.; BAYÃO, G. F.; GOMES, M. P. C. In vitro degradation of neutral detergent fiber of lowquality tropical forage according to supplementation with true protein and (or) non-protein nitrogen. Revista Brasileira de Zootecnia, Viçosa, MG, v. 40, n. 6, p. 12721279, 2011.

DETMANN, E.; SOUZA, M. A.; VALADARES FILHO, S. C.; QUEIROZ, A. C.; BERCHIELLI, T. T.; SALIBA, E. O. S.; CABRAL, L. S.; PINA, D. S.; LADEIRA, M. M.; AZEVEDO, J. A. G. Métodos para análise de alimentos. Visconde do Rio Branco: Instituto Nacional de Ciência e Tecnologia de Ciência Animal-INCT, Suprema, 2012. 214 p.

DETMANN, E.; VALADARES FILHO, S. C.; PAULINO, M. F.; HUHTANEN, P. Nutritional aspects applied to grazing cattle in tropics: a review based on Brazilian results. Semina: Ciências Agrárias, Londrina, v. 35 , n. 4 , p. 2829-2854, 2014a.

DETMANN, E.; VALENTE, E. E. L.; BATISTA, E. D.; HUHTANEN, P. An evaluation of performance and efficiency of nitrogen utilization in cattle feed tropical grass pastures with supplementation. Livestock Science, Amsterdam, v. 162, n. 1, p. 141-153, 2014 b.

FORDYCE, J.; COOPER, N. J.; KENDALL, I. E. Creep feeding and prepartum supplementation effects on growth and fertility of Brahman-cross cattle in the dry tropics. Australian Journal of Experimental Agriculture, v. 36, n. 4, p. 389-395, 1996

HENRIQUES, L. T.; VALADARES FILHO, S. C.; FONSECA, M. A.; PAULINO, P. V. R.; DETMANN, E.; VALADARES, R. F. D. Evaluation of non-linear models and the effects of primiparous cows and calved intake on the lactation curve of Nellore cows. Revista Brasileira de Zootecnia, Viçosa, MG, v. 40, n. 6, p. 1287-1295, 2011.

LAZZARINI, I.; DETMANN, E.; SAMPAIO, C. B.; PAULINO, M. F.; VALADARES FILHO, S. C.; SOUZA, M. A.; OLIVEIRA, F. A. Intake and digestibility in cattle fed low-quality-tropical forage and supplemented with nitrogenous compounds. Revista Brasileira de Zootecnia, Viçosa, MG, v. 38, n. 10, p. 2021-2030, 2009.

LOPES, S. A.; PAULINO, M. F.; DETMANN, E.; VALADARES FILHO, S. C.; VALENTE, E. E. L.; BARROS, L. V.; CARDENAS, J. E. G.; ALMEIDA, D.
M.; MARTINS, L. S.; SILVA, A. G. Supplementation of suckling beef calves with different levels of crude protein on tropical pasture. Tropical Animal Health and Production, Edinburgh, v. 46, n. 1, p. 379-384, 2014.

MARQUEZ, D. C.; PAULINO, M. F.; MARCONDES, M. I.; RENNÓ, L. N.; BARROS, L. V.; MARTINS, L. S.; ORTEGA, R. M.; SILVA, A. G.; ALMEIDA, D. M.; MORENO, D. P. S.; MOURA, F. H. Nutritional and productive parameters of calves on pasture supplemented with different sources of protein foods. Semina: Ciencias Agrárias, Londrina, v. 35, n. 5, p. 2709-2722, 2014.

NATIONAL RESEARCH COUNCIL - NRC. Nutrients requirements of beef cattle. $7^{\text {th }}$ ed. Washington: National Academic Press, 1996. 242 p.

Nutrient requirements of dairy cattle. $7^{\text {th }}$ ed. Washington: National Academic Press, 2001. 381 p.

PAULA, N. F. Crescimento de bovinos de corte no sistema pasto/suplemento submetidos a diferentes planos nutricionais. 2012. Tese (Doutorado em Ciência Animal) - Universidade Federal de Viçosa, Viçosa, MG.

PAULINO, M. F.; DETMANN, E.; SILVA, A. G.; ALMEDA, D. M.; MÁRQUEZ, D. C.; MORENO, D. P. S.; MOURA, F. H.; CARDENAS, J. E. G.; LIMA, J. A. C.; MARTINS, L. S.; MANSO, M. R.; ORTEGA, R. M.; LOPES, S. A.; CARVALHO, V. V. Cattle production optimized. In: INTERNATIONAL SYMPOSIUM ON BEEF CATTLE PRODUCTION, 5., 2014, Viçosa, MG. Proceeding... Viçosa, MG: UFV, 2014. p. 139-164.

PAULINO, M. F.; DETMANN, E.; SILVA, A. G.; ALMEIDA, D. M.; VALENTE, E. E. L.; MACIEL, I. F. S.; MARTINS, L. S.; BARROS, L. V.; PAULA, N. F.; LOPES, S. A.; CARVALHO, V. V. Cattle production of high performance with sustainability. In: INTERNATIONAL SYMPOSIUM ON BEEF CATTLE PRODUCTION, 4., 2012, Viçosa, MG. Proceeding... Viçosa, MG: UFV, 2012. p. 184-196.

PAULINO, M. F.; DETMANN, E.; VALADARES FILHO, S. C. Functional production of cattle in the tropics. In: INTERNATIONAL SYMPOSIUM ON BEEF CATTLE PRODUCTION, 2., 2008, Viçosa, MG. Proceeding... Viçosa, MG: UFV, 2008. p. 275-305.

PAULINO, P. V. R.; FONSECA, M. A.; HENRIQUES, L. T.; VALADARES FILHO, S. C.; DETMANN, E. Nutritional requirements of cows and calves nelore BRCORTE. Viçosa, MG: DZO/UFV, 2010. 193 p.

POPPI, D. P.; MACLENNAN, S. R. Protein and energy utilization by ruminants at pasture. Journal. Animal Science, Baltimore, v. 73, n. 2, p. 278-290, 1995. 
PORTO, M. O.; PAULINO, M. F.; VALADARES FILHO, S. C.; DETMANN, E.; SALES, M. F. L.; COUTO, V. R. M. Energy sources in multiple supplements for Nellore calves in creep-feeding: productive performance, intake and digestibility of nutrients. Revista Brasileira Zootecnia, Viçosa, MG, v. 38, n. 7, p. 1329-1339, 2009.

SCHROEDER, G. F.; TITGEMEYER, E. C. Interaction between protein and energy supply on protein utilization in growing cattle: a review. Livestock Science, Amsterdam, v. 114, n. 1, p. 1-10, 2008.

SOUZA, M. A.; DETMANN, E.; PAULINO, M. F.; SAMPAIO, C. B.; LAZZARINI, I.; VALADARES, S. C. Intake, digestibility and rumen dynamics of neutral detergent fiber in cattle fed lowquality tropical forage and supplemented with nitrogen and/or starch. Tropical Animal Health and Production, Edinburgh, v. 42, n. 1, p. 1299-1310, 2010.
VALADARES, R. F. D.; BRODERICK, G. A.; VALADARES FILHO, S. C.; CLAYTON, M. K. Effect of replacing alfalfa silage with high moisture corn on ruminal protein synthesis estimated from excretion of total purine derivatives. Journal Dairy Science, Madison, v. 82 , n. 11 , p. 2686- $2696,1999$.

VALENTE, E. E. L.; PAULINO, M. F.; BARROS, L. V.; ALMEIDA, D. M.; MARTINS, L. S.; CABRAL, C. H. A. Effect of calves supplementation on performance, nutritional and behavioral characteristics of their dams. Tropical Animal Health and Production, Edinburgh, v. 45, n. 2, p. 487-495, 2013.

VARGAS JUNIOR, F. M.; WECHSLER, F. S.; ROSSI, P.; OLIVEIRA, M. V. M.; SCHMIDT, P. Voluntary intake of dry matter and performance of Nellore cows and their Nellore and crossbred Simental $\times$ Nellore calves. Revista Brasileira de Zootecnia, Viçosa, MG, v. 40, n. 11, p. 2575-2581, 2011. 
